\title{
Penentuan Titik Lokasi Pelabuhan Penyeberangan Amed Di Kabupaten Karangasem
}

\author{
I Gusti Ngurah Putra Dirgayusa \\ Program Studi Ilmu Kelautan, Fakultas Kelautan dan Perikanan, Universitas Udayana, Bukit Jimbaran, Bali 80361, Indonesia \\ Penulis koresponden. Tel.: +62-361-702-802 \\ Alamate-mail:dirga@civil.unud.ac.id \\ Diterima (received) 8 Januari 2016; disetujui (accepted) 29 Mei 2016; tersedia secara online (available online) 4 Juni 2016
}

\begin{abstract}
Accumulation of social activity, economy and transportation that occur in Southern part of Bali adversely affects at transportation infrastructure carrying activity in this area. These require the government to get the solution of this problem. Through spatial planning area of Bali province 2005, governments establish Amed Bay developed as crossing harbor. These cases mean to divide the shout hem traffic line and support the development in northern part of Bali. The object of this research is in Purwakerti village, district of Abang, Karangasem regency. Research held based on technical and legality review. In advance analyze of those aspects that established some alterative potential location based on area requirement and mapping survey result. Following, each location alternative disassembly and examined their advantages and disadvantages in each aspect. Technical aspect analyze of land and territorial water technique. The approach that used in harbor location selection for this technique is weighting and assessment method in assessment matrix. The weighting value that used refers to harbor location selection in Makian bay. Meanwhile, for legality aspect, analyzed by policy review that relate to spatial area and location selection of harbor development. Based on minimum area demand analyze that 0.7 Ha for land facilities and 15.8 Ha for waters facilities. Refers to minimum area demand and layout spatial survey, four locations are selected for alternative points. After technical and legality aspect analyzed, then obtained second area chosen which located in Amed country, Purwakerti village.
\end{abstract}

Keywords: port; location; Amed; social; legality

\begin{abstract}
Abstrak
Penumpukan aktifitas sosial, ekonomi dan transportasi yang terjadi di kawasan Bali Selatan berakibat pada menurunnya daya dukung infrastruktur transportasi di wilayah ini. Hal ini menuntut pemerintah untuk mencari solusi masalah yang dihadapi. Melalui Rencana Tata Ruang Wilayah Propinsi Bali tahun 2005 pemerintah menetapkan Pelabuhan Amed dikembangkan sebagai pelabuhan penyeberangan. Hal ini dimaksudkan untuk membagi beban lalu lintas jalur Lintas Selatan dan untuk menunjang perkembangan pembangunan di wilayah Bali Utara. Penelitian ini mengambil obyek studi di Desa Purwakerti, Kecamatan Abang, Kabupaten Karangasem. Penelitian dilakukan berdasarkan kajian teknis dan legalitas. Sebelum dilakukan analisis pada aspek-aspek tersebut, terlebih dahulu ditetapkan beberapa alternatif lokasi yang potensial dilihat dari kebutuhan lahan dan hasil survei pemetaan. Setelah didapatkan alternatif lokasi selanjutnya setiap alternatif lokasi diuraikan dan diteliti keunggulan dan kelemahannya pada masingmasing aspek. Aspek teknis menguraikan tentang aspek teknis daratan dan perairan. Pendekatan yang digunakan dalam pemilihan lokasi pelabuhan untuk aspek teknis ini adalah metode pembobotan dan penilaian dalam bentuk matriks penilaian. Nilai pembobotan yang digunakan mengacu pada studi pemilihan lokasi pelabuhan di Pelabuhan Makian. Sedangkan untuk aspek legalitas, analisis dilakukan dengan tinjauan kebijakan yang berlaku berkaitan dengan tata ruang wilayah dan pemilihan lokasi pembangunan pelabuhan. Berdasarkan analisis kebutuhan lahan minimum yang diperoleh adalah 0,7 Ha untuk fasilitas daratan dan 15,8 Ha untuk fasilitas perairan. Dari kebutuhan lahan minimum dan hasil survei pemetaan terpilih empat titik alternatif lokasi. Setelah dilakukan analisis pada aspek teknis dan legalitas akhirnya didapat lokasi terpilih yaitu alternatif dua yang terletak di Dusun Amed, Desa Purwakerti.
\end{abstract}

Kata Kunci: pelabuhan; lokasi; Amed; sosial; legalitas

\section{Pendahuluan}

Sejak jaman penjajahan Belanda Teluk Amed digunakan sebagai tempat berlabuhnya kapal. Hal ini menunjukkan bahwa Teluk Amed sudah memadai dari teknis keselamatan pelayaran. Pada kondisi sekarang ini Teluk Amed banyak digunakan oleh kapal-kapal 40 PK untuk menyeberang ke Pelabuhan Ampenan, Lombok Barat. Informasi dari nelayan yang melakukan penyeberangan dari Amed ke Ampenan hanya memerlukan waktu kurang lebih tiga jam. Sedangkan penyeberangan Padangbai Lembar sekarang ini memakan waktu empat sampai lima jam.

Berdasarkan data aksesibilitas lokasi rencana Pelabuhan Amed yang terletak di bagian Timur Laut Bali telah dilintasi jaringan jalan lingkar Bali, sehingga mudah diakses dari seluruh wilayah Bali maupun luar Bali. Akses ke rencana lokasi Pelabuhan Amed dari kota-kota di 
wilayah Bali dapat dilakukan dengan menggunakan kendaraan roda empat baik kendaraan angkutan barang maupun kendaraan angkutan penumpang melalui jaringan jalan yang tersedia baik jalan nasional, jalan propinsi maupun jalan kabupaten/lokal.

Teluk Amed yang memiliki panjang $\pm 16 \mathrm{~km}$ menyediakan beberapa alternatif lokasi penempatan pelabuhan. Alternatif-alternaif lokasi tersebut harus dipertimbangkan secara matang untuk mendapatkan lokasi terbaik mengingat untuk membangun suatu pelabuhan diperlukan biaya yang besar. Oleh karena itu, berdasarkan hal tersebut di atas, maka perlu dilakukan suatu kajian yang lebih mendalam lagi tentang pemilihan lokasi pada Perencanaan Pelabuhan Amed, khususnya ditinjau dari aspek teknis, sosial dan legalitas.

\section{Kajian Pustaka}

\subsection{Pengertian}

Pelabuhan (port) adalah perairan yang terlindung dari gelombang, yang dilengkapi dengan fasilitas terminal laut meliputi dermaga tempat kapal dapat bertambat untuk bongkar muat barang, kran-kran untuk bongkar muat barang, gudang laut (transito) dan tempat-tempat penyimpanan dimana kapal membongkar muatannya, dan gudang-gudang dimana barang-barang dapat disimpan dalam waktu yang lebih lama selama menunggu pengiriman ke daerah tujuan atau pengapalan. Terminal ini biasanya dilengkapi dengan jalan kereta api, jalan raya atau saluran pelayaran darat.

Dalam perkembangan selanjutnya menurut Peraturan Pemerintah Republik Indonesia nomor 11 tahun 1983, pengertian pelabuhan mencakup pengertian sebagai prasarana dan sistem yaitu pelabuhan adalah suatu lingkungan kerja terdiri dari area daratan dan perairan yang dilengkapi dengan fasilitas tempat berlabuh dan bertambatnya kapal, untuk terselenggaranya bongkar muat serta turun naiknya penumpang, dari suatu moda transportasi laut (kapal) ke moda transportasi lainnya dan sebaliknya (Budiartha dan Arnatha, 2000).

Dalam Keputusan Menteri Perhubungan Nomor 53 Tahun 2002 disebutkan bahwa di Indonesia pelabuhan penyeberangan menurut peran dan fungsinya dibedakan menjadi tiga, yaitu:

1. Pelabuhan penyeberangan lintas propinsi/antar negara, ditetapkan dengan memperhatikan fungsi jalan yang dihubungkan yaitu jalan nasional dan jalan antar negara;

2. Pelabuhan penyeberangan lintas kabupaten/kota, ditetapkan dengan memperhatikan fungsi jalan yang dihubungkan yaitu jalan propinsi; dan

3. Pelabuhan penyeberangan lintas dalam kabupaten/kota, ditetapkan dengan memperhatikan fungsi jalan yang dihubungkannya yaitu jalan Kabupaten/Kota.

Dalam Pedoman Teknis Pemilihan dan Penetapan Lokasi Pelabuhan Di Indonesia disebutkan bahwa, perencanaan pembangunan pelabuhan di Indonesia dilakukan melalui tiga tahapan, yaitu :
1. Penentuan lokasi pelabuhan yang harus didukung dengan survei teknis secara garis besar beserta indikasi kebutuhan pelabuhan di masa datang (20 tahun), keluaran penetapan lokasi berupa koordinat geografis keberadaan pelabuhan serta indikasi kebutuhan ruang daratan dan perairan pelabuhan di masa datang. Selain itu keterkaitan rencana lokasi pelabuhan dengan pelabuhan-pelabuhan lain dalam sistem kepelabuhanan.

2. Studi master plan dan kelayakan pembangunan (teknis, ekonomis dan lingkungan), yang harus didukung dengan hasil survei tentang potensi hinterland, aktivitas ekonomi, kondisi sosial, teknis (hidrografi, oceanografi, topografi, dan penyelidikan tanah), dan lingkungan. Keluaran studi ini berupa rencana blok/zona pemanfaatan ruang daratan dan perairan pelabuhan untuk 20 tahun target rencana serta tahapan, pembangunan jangka pendek (5 tahun), jangka menengah (10 tahun), dan jangka panjang (20 tahun) mendatang. Setelah itu diikuti dengan studi kelayakan pembangunan tahap 5 tahun pertama (jangka pendek). Keluaran studi telah menyesuaikan dengan peraturan daerah seperti Rencana Tata Ruang Kota/Kabupaten (RTRK), SIPPT (Surat Ijin Penunjukkan Penggunaan Tanah), SP3L (Surat Persetujuan Prinsip Pembebasan Lokasi/Lahan).

3. Desain Fasilitas Pelabuhan, yaitu proses perencanaan yang paling detail menyangkut pembangunan pelabuhan, baik itu sisi daratan maupun pada sisi perairan.

Tahap yang mendasar dan penting dalam proses perencanaan pelabuhan adalah tahap penentuan lokasi pelabuhan. Dari beberapa usulan lokasi yang diajukan karena memiliki potensi, pertimbangan dan prospek yang baik akan dikaji dari berbagai aspek yang dapat dibadingkan keuntungan/keunggulan dan kerugian/ kelemahan, sebagai justifikasi teknis dalam menentukan rekomendasi lokal.

\subsection{Pemilihan lokasi pelabuhan}

Dalam Keputusan Menteri Perhubungan Nomor 52 Tahun 2002 disebutkan aspek yang harus diperhatikan dalam penetapan lokasi pelabuhan di Indonesia, yaitu:

1. Tatanan Kepelabuhanan Nasional (TKN), yaitu dengan mengidentifikasi peran, fungsi dan kepentingannya di dalam tatanan tersebut.

2. Kesesuaian dengan Rencana Tata Ruang Wilayah Kabupaten/Kota dan Rencana Tata Ruang Wilayah Propinsi.

3. Aspek kelayakan teknis dengan memperhatikan kondisi dan kapasitas daratan serta perairan (alur dan kolam), bathimetri, kedalaman perairan, karakteristik gelombang, karakteristik pasang surut dan arus, erosi dan pengendapan, kondisi lapisan tanah, luas daratan dan topografi.

4. Aspek ekonomis dengan memperhatikan produk domestik regional bruto, aktivitas/ perdagangan dan industri yang ada serta prediksi di masa datang, perkembangan aktivitas barang dan penumpang, kontribusi pada peningkatan taraf hidup penduduk 
dan perhitungan ekonomi/finansial bagi kegiatan kepelabuhanan yang berkelanjutan.

5. Pertumbuhan ekonomi dan perkembangan sosial yang berdampak pada peningkatan aktivitas penumpang, barang dan hewan dari dan keluar pelabuhan.

6. Kelayakan lingkungan dengan memperhatikan daya dukung lokasi, daerah perlindungan dan suaka flora dan fauna.

7. Keterpaduan intra dan antar moda transportasi.

8. Adanya aksesibilitas terhadap hinterland untuk kelancaran distribusi termasuk aksesibilitas dari dan keluar pelabuhan.

9. Keamanan dan keselamatan pelayaran di rencana lokasi dapat terjamin.

10. Pertahanan dan keamanan negara.

Keputusan pembangunan pelabuhan biasanya didasarkan pada pertimbangan-pertimbangan ekonomi, legalitas, teknis, operasional, sosial dan lingkungan. Untuk menentukan layak atau tidaknya suatu lokasi dijadikan suatu pelabuhan maka semua aspek tersebut harus diusahakan dapat terpenuhi secara optimal, namun pada kenyataannya tidaklah mungkin untuk memenuhi semua kondisi di atas, sehingga diperlukan suatu kompromi untuk mendapatkan hasil yang optimal, salah satunya terpaksa diabaikan. Atau pada suatu lokasi kemungkinan terdapat keuntungan yang sangat menonjol atau sebaliknya. (Budiartha dan Arnatha, 1999).

\section{Metode Penelitian}

\subsection{Tahap pemilihan lokasi}

Langkah awal yang dibutuhkan adalah menetapkan suatu dasar kriteria yang berpengaruh sangat signifikan dan melakukan penilaian-penilaian terhadap dasar atau kriteria penentuan lokasi. Metode penilaian yang dipakai disini terdiri dari bobot dan nilai dari setiap kriteria-kriteria tersebut. Lokasi yang direkomendasikan sebagai lokasi terbaik ditentukan berdasarkan jumlah nilai tertinggi yang diperoleh alternatif yang ditinjau.

\subsection{Aspek teknis}

Dalam Laporan Teknis Pekerjaan Survei, Desain dan Investigasi Dermaga Penyeberangan Padangbai II-Lembar II Departemen Perhubungan tahun 2004, faktor yang dipertimbangkan pada masing-masing lokasi diberi nilai (N) dengan bobot (B) tertentu. Skala nilai (N) tersebut diupayakan secara kuantitatif dengan memperhatikan penilaian yang lazim sebagai berikut:

$\begin{array}{lll}10 & = & \text { Sempurna } \\ 9 & = & \text { Baik Sekali } \\ 8 & = & \text { Baik } \\ 7 & = & \text { Cukup Baik } \\ 6 & = & \text { Dapat Diterima } \\ 5 & = & \text { Kurang } \\ 4 & = & \text { Buruk } \\ 3 & = & \text { Tidak Memenuhi Syarat. }\end{array}$

Persentase pembobotan yang digunakan mengacu pada suatu studi pemilihan lokasi pelabuhan yang dilakukan oleh Departemen Perhubungan pada tahun 2004 di Padangbai dan Lembar serta pada tahun 2007 di Makian. Dalam studi pemilihan lokasi pelabuhan di Padangbai dan Lembar digunakan 9 buah faktor, sedangkan untuk studi di Makian digunakan 10 buah faktor dengan penambahan faktor yaitu sedimentasi.

Dengan penggunaan faktor yang lebih banyak tentu akan mempertajam dan memperbanyak faktor acuan dalam pemilihan lokasi pelabuhan, sehingga karena alasan tersebut dalam penelitian ini dipakai 10 buah faktor seperti terlihat pada Tabel 1 .

Tabel 1.

Matriks Penilaian Aspek Teknis

\begin{tabular}{|c|c|c|c|c|c|c|c|c|c|c|}
\hline \multirow{2}{*}{ No } & \multirow{2}{*}{ Uraian } & \multirow{2}{*}{$\begin{array}{c}\text { B } \\
\%\end{array}$} & \multicolumn{2}{|c|}{ Alt. 1} & \multicolumn{2}{|c|}{ Alt. 2} & \multicolumn{2}{|c|}{ Alt. 3} & \multicolumn{2}{|c|}{ Alt. 4} \\
\hline & & & $\mathbf{N}$ & $B * \mathbf{N}$ & $\mathbf{N}$ & $B * \mathbf{N}$ & $\mathbf{N}$ & $B * \mathbf{N}$ & $\mathbf{N}$ & $B * N$ \\
\hline 1 & \begin{tabular}{|l|} 
Jarak \\
kedalaman \\
minimum \\
\end{tabular} & 9 & & & & & & & & \\
\hline 2 & Arus dominan & 9 & & & & & & & & \\
\hline 3 & Pasang surut & 8 & & & & & & & & \\
\hline 4 & $\begin{array}{l}\text { Gelombang } \\
\text { dominan }\end{array}$ & 11 & & & & & & & & \\
\hline 5 & Sedimentasi & 9 & & & & & & & & \\
\hline 6 & Alur pelayaran & 11 & & & & & & & & \\
\hline 7 & Aksesibilitas & 14 & & & & & & & & \\
\hline 8 & $\begin{array}{l}\text { Ketersediaan } \\
\text { lahan }\end{array}$ & 14 & & & & & & & & \\
\hline 9 & Kondisi Lahan & 8 & & & & & & & & \\
\hline 10 & $\begin{array}{l}\text { Fasilitas } \\
\text { pendukung }\end{array}$ & 7 & & & & & & & & \\
\hline & Total : & 100 & & & & & & & & \\
\hline
\end{tabular}

Ket: $\mathrm{B}=$ Bobot; $\mathrm{N}=$ Nilai; Alt. $=$ Alternatif

\subsection{Aspek sosial}

Seperti aspek teknis, aspek sosial juga memiliki kontribusi sama pentingnya dalam pertimbangan pembangunan suatu pelabuhan. Berbeda halnya dengan analisis yang dilakukan pada aspek teknis, analisis yang dilakukan pada aspek sosial adalah analisis statistik deskriptif. Aspek sosial dikatakan terpenuhi jika masyarakat mendukung adanya pembangunan pelabuhan pada lokasi tersebut.

\subsection{Aspek legalitas}

Aspek legalitas merupakan suatu aspek yang sangat menentukan dalam pembangunan suatu pelabuhan. Tanpa adanya legalitas yang jelas, maka rekomendasi suatu lokasi pelabuhan tidak akan pernah dikeluarkan oleh pejabat yang berwenang. Analisa yang digunakan pada aspek ini yaitu dengan tinjauan kebijakan pada peraturanperaturan terkait. Aspek ini dikatakan terpenuhi apabila tidak ada benturan kepentingan dengan peraturanperaturan terkait yang berlaku dan juga aspek-aspek lain dalam pemilihan suatu lokasi pelabuhan. 


\subsection{Lokasi terpilih}

Lokasi terpilih adalah lokasi dengan bobot terbesar pada analisis aspek teknis, layak pada kajian aspek sosial dalam hal ini dukungan masyarakat dan kajian terhadap peraturan-peraturan terkait masalah kepelabuhanan.

\section{Hasil dan Pembahasan}

\subsection{Faktor-faktor penentuan lokasi}

Pada tahap awal terdapat beberapa faktor yang perlu diperhatikan dalam menentukan alternatif lokasi pelabuhan. Beberapa faktor ini dapat dijadikan dasar acuan pemilihan alternatif lokasi. Setiap alternatif lokasi yang telah ditentukan selanjutnya akan dianalisis untuk mendapatkan lokasi terpilih. Beberapa faktor tersebut meliputi penentuan karakteristik kapal rencana, analisis kebutuhan lahan dan penentuan tipe dermaga yang akan digunakan.Dari hasil survei pemetaan terdapat 4 alternatif lokasi yang mungkin untuk dikembangkan sebagai pelabuhan antara lain dapat dilihat pada Tabel 2, sedangkan secara geografis dapat dilihat pada Gambar 1 .

\subsection{Analisis Teknis}

Jarak kedalaman minimum berkaitan dengan biaya pembangunan, semakin pendek jarak ini maka biaya pembangunan akan semakin kecil. Semakin pendek jarak yang diperlukan untuk mencapai kedalaman yang diperlukan diberikan nilai yang besar. Pada kondisi perairan di Amed dengan jarak 35-150 m kedalaman minimum sudah didapatkan, sehingga indikator yang digunakan antara lain untuk jarak $<25 \mathrm{~m}$ diberi nilai 10 dan untuk jarak $>300 \mathrm{~m}$ diberi nilai terkecil yaitu 3 . Berbeda dengan studi di Pelabuhan Makian digunakan indikator jarak $<25 \mathrm{~m}$ sampai $>1500 \mathrm{~m}$. Menimbang jarak kedalaman minimum berkaitan dengan biaya pembangunan maka bobot yang diberikan adalah $9 \%$.

Kecepatan arus dominan akan berpengaruh besar terhadap manuver kapal dan juga biaya pembangunan. Semakin kecil kecepatan arus dominan maka akan semakin memudahkan manuver kapal, dengan demikian kecepatan arus dominan yang kecil diberi nilai yang besar. Menimbang hal tersebut maka kriteria arus dominan diberi bobot 9 .

Pasang surut berpengaruh pada operasional bongkar muat serta biaya pembangunan. Semakin kecil beda pasang surut akan lebih menguntungkan karena elevasi

Tabel 2.

Alternatif Lokasi Pelabuhan.

\begin{tabular}{|c|c|c|c|c|c|}
\hline No. & Alternatif & Koordinat & Kebutuhan Lahan & Keperluan & Eksisting \\
\hline \multirow[t]{2}{*}{1} & \multirow[t]{2}{*}{$\begin{array}{l}\text { Alternatif ke-1 } \\
\text { Dusun Jemuluk, Desa } \\
\text { Purwakerti, } \\
\text { Kecamatan Abang } \\
\text { (Teluk Jemuluk) }\end{array}$} & \multirow[t]{2}{*}{$\begin{array}{l}8^{\circ} 20^{\prime} 12,85^{\prime \prime} \text { LS dan } \\
115^{\circ} 39^{\prime} 37,01^{\prime \prime} \mathrm{BT}\end{array}$} & $\begin{array}{l}\text { 1. Daratan } \\
\text { - Luasan } \\
\text { - Kemiringan } \\
\text { - Pengembangan }\end{array}$ & $\begin{array}{l}0,7 \mathrm{Ha} \\
0-8 \% \\
-\end{array}$ & $\begin{array}{c}1-2 \mathrm{Ha} \\
7,3 \% \\
\text { memungkinkan }\end{array}$ \\
\hline & & & $\begin{array}{l}\text { 2. Perairan } \\
\text { - Luasan } \\
\text { - Jarak untuk mencapai kedalaman } \\
5,5 \mathrm{~m}\end{array}$ & $\begin{array}{c}15,8 \mathrm{Ha} \\
-\end{array}$ & $\begin{array}{l}0-20 \mathrm{Ha} \\
70-80 \mathrm{~m}\end{array}$ \\
\hline \multirow[t]{2}{*}{2} & \multirow{2}{*}{$\begin{array}{l}\text { Alternatif ke-2 } \\
\text { Dusun Amed, Desa } \\
\text { Purwakerti, } \\
\text { Kecamatan Abang } \\
\text { (sebelah utara Pusat } \\
\text { Pelelangan Ikan) }\end{array}$} & \multirow[t]{2}{*}{$\begin{array}{l}8^{\circ} 19^{\prime} 56,78^{\prime \prime} \text { LS dan } \\
115^{\circ} 38^{\prime} 29,44^{\prime \prime} \text { BT }\end{array}$} & $\begin{array}{l}\text { 1. Daratan } \\
\text { - Luasan } \\
\text { - Kemiringan } \\
\text { - Pengembangan }\end{array}$ & $\begin{array}{c}0,7 \mathrm{Ha} \\
0-8 \% \\
-\end{array}$ & $\begin{array}{c}2-5 \mathrm{Ha} \\
0,95 \% \\
\text { memungkinkan }\end{array}$ \\
\hline & & & $\begin{array}{l}\text { 2. Perairan } \\
\text { - Luasan } \\
\text { - Jarak untuk mencapai kedalaman } \\
5,5 \mathrm{~m}\end{array}$ & $\begin{array}{c}15,8 \mathrm{Ha} \\
-\end{array}$ & $\begin{array}{l}0-100 \mathrm{Ha} \\
35-50 \mathrm{~m}\end{array}$ \\
\hline \multirow[t]{2}{*}{3} & \multirow{2}{*}{$\begin{array}{l}\text { Alternatif ke-3 } \\
\text { Dusun Babakan, } \\
\text { Desa Purwakerti, } \\
\text { Kecamatan Abang } \\
\text { (sebelah utara tempat } \\
\text { melasti) }\end{array}$} & \multirow[t]{2}{*}{$\begin{array}{l}8^{\circ} 19^{\prime} 48,18^{\prime \prime} \text { LS dan } \\
115^{\circ} 38^{\prime} 25,06^{\prime \prime} \mathrm{BT}\end{array}$} & $\begin{array}{l}\text { 1. Daratan } \\
\text { - Luasan } \\
\text { - Kemiringan } \\
\text { - Pengembangan }\end{array}$ & $\begin{array}{c}0,7 \mathrm{Ha} \\
0-8 \% \\
-\end{array}$ & $\begin{array}{c}2-4 \mathrm{Ha} \\
0,93 \% \\
\text { memungkinkan }\end{array}$ \\
\hline & & & $\begin{array}{l}\text { 2. Perairan } \\
\text { - Luasan } \\
\text { - Jarak untuk mencapai kedalaman } \\
5,5 \mathrm{~m}\end{array}$ & $\begin{array}{c}15,8 \mathrm{Ha} \\
-\end{array}$ & $\begin{array}{l}0-100 \mathrm{Ha} \\
99-105 \mathrm{~m}\end{array}$ \\
\hline \multirow[t]{2}{*}{4} & \multirow{2}{*}{$\begin{array}{l}\text { Alternatif ke-4 } \\
\text { Dusun Babakan, } \\
\text { Desa Purwakerti, } \\
\text { Kecamatan Abang } \\
\text { (dekat Tukad } \\
\text { Bangka) }\end{array}$} & \multirow[t]{2}{*}{$\begin{array}{l}8^{\circ} 19^{\prime} 30,59^{\prime \prime} \text { LS dan } \\
115^{\circ} 38^{\prime} 03,45^{\prime \prime} \mathrm{BT}\end{array}$} & $\begin{array}{l}\text { 1. Daratan } \\
\text { - Luasan } \\
\text { - Kemiringan } \\
\text { - Pengembangan }\end{array}$ & $\begin{array}{l}0,7 \mathrm{Ha} \\
0-8 \% \\
-\end{array}$ & $\begin{array}{c}2-3 \mathrm{Ha} \\
1,08 \% \\
\text { memungkinkan }\end{array}$ \\
\hline & & & $\begin{array}{l}\text { 2. Perairan } \\
\text { - Luasan } \\
\text { - Jarak untuk mencapai kedalaman } \\
5,5 \mathrm{~m}\end{array}$ & $\begin{array}{c}15,8 \mathrm{Ha} \\
-\end{array}$ & $\begin{array}{l}0-100 \mathrm{Ha} \\
90-100 \mathrm{~m}\end{array}$ \\
\hline
\end{tabular}




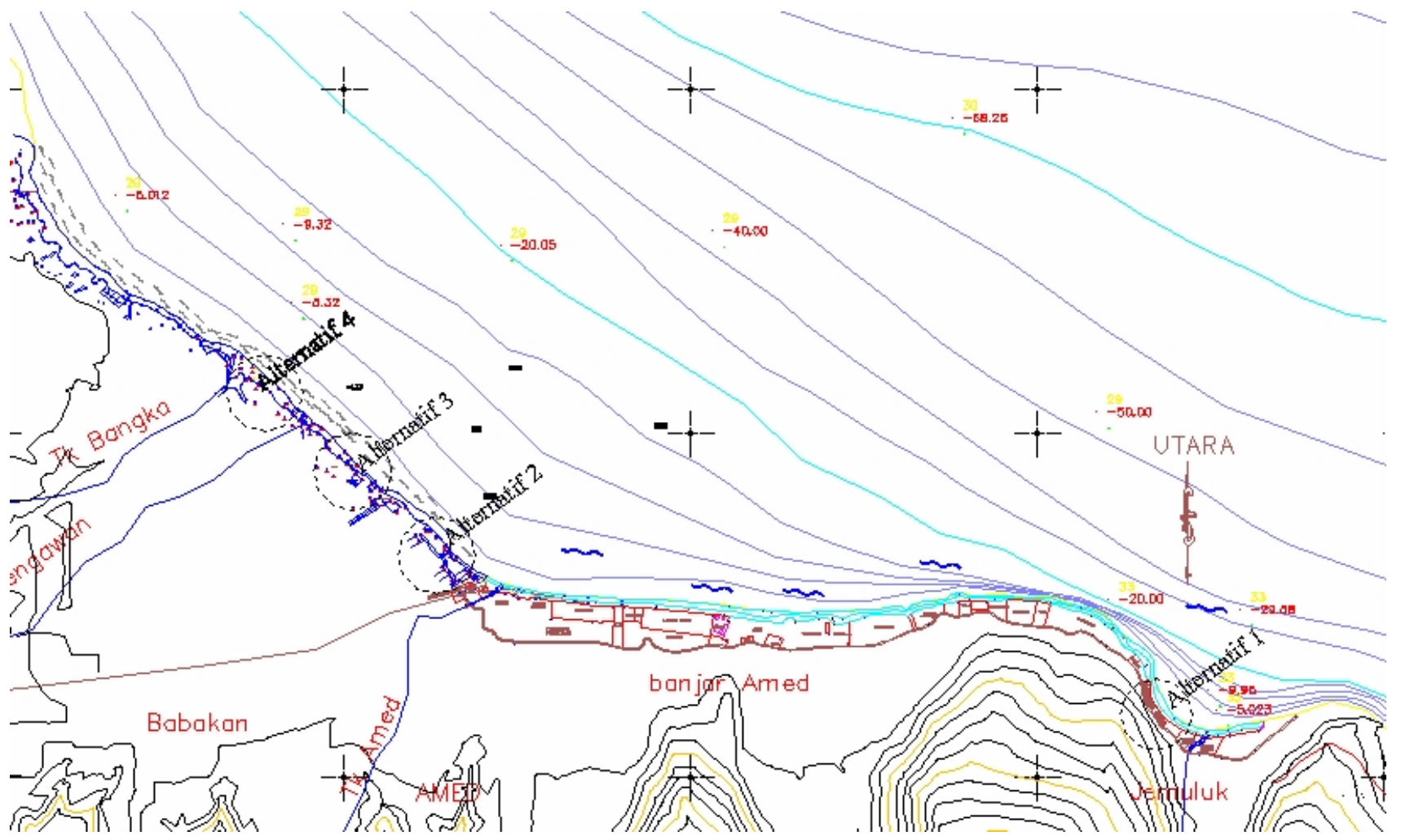

Gambar 1. Posisi ke empat lokasi pelabuhan alternatif

bangunan-bangunan laut menjadi lebih rendah dan sarana bongkar muat dapat dibuat lebih sederhana. Dengan demikian pasang surut yang kecil diberikan nilai yang besar. Sedangkan untuk pemberian bobot, menimbang pasang surut berpengaruh terhadap biaya pembangunan maka kriteria pasang surut ini diberi bobot 8 .

Tinggi gelombang dominan berpengaruh besar pada operasional kapal dan biaya pembangunan. Apabila frekuensi dan besarnya gelombang di lokasi areal cukup tinggi maka akan sangat menghambat operasional kapal bahkan membahayakan, sehingga diperlukan bangunan pemecah gelombang yang menyebabkan tingginya biaya konstruksi. Karena kriteria ini sangat penting bobot yang diberikan adalah $11 \%$. Sedangkan untuk pemberian nilai indikator, semakin kecil tinggi gelombang dominan maka semakin besar nilai yang diberikan.

Adanya sedimentasi/pendangkalan dapat mengganggu pengoperasian pelabuhan sehingga harus dilakukan pengerukan secara berkala dan memerlukan biaya operasional yang cukup mahal serta terhentinya pelayaran penyeberangan. Analisis pendangkalan untuk suatu konfigurasi bangunan laut/pantai pada umumnya terdiri dari analisis simulasi komputer dengan parameterparemeter input dari hasil survey dan dikhususkan untuk itu. Survey semacam ini berada di luar penentuan lokasi pelabuhan, namun dalam skala kecil yang kasar keberadaan serta jarak suatu sungai ke lokasi alternatif dapat dijadikan acuan dalam penentuan penilaian. Di pesisir Amed sendiri bermuara empat buah sungai yang berjarak 136-2924 m dari masing-masing lokasi alternatif. Sehingga indikator penilaian yang digunakan antara lain untuk jarak sungai $<50 \mathrm{~m}$ diberi nilai 3 dan untuk jarak sungai $>2000 \mathrm{~m}$ diberi terbesar yaitu 10. Berbeda dengan indikator yang dipakai pada studi Pelabuhan Penyeberangan Makian, indikator yang dipakai hanya sebatas jauh atau dekatnya sungai dengan lokasi pelabuhan.

Dengan ketentuan bahwa semakin jauh jarak antara sungai dengan lokasi maka nilai yang diberikan akan lebih besar. Menimbang sedimentasi berpengaruh terhadap pengoperasian pelabuhan dan juga biaya operasional maka kriteria ini diberi bobot 9 .

Indikator yang digunakan dalam kriteria alur pelayaran adalah lebar dan kedalaman. Alur pelayaran terkait pada faktor keamanan dan kemudahan kapal menuju ke dermaga, maka alur pelayaran yang lebar dan kedalaman alur yang dalam diberi nilai yang besar. Menimbang lebar dan kedalaman alur pelayaran ini berkaitan langsung dengan faktor keselamatan pelayaran, maka diberi bobot $11 \%$.

Mengingat pelabuhan penyeberangan merupakan simpul kekuatan perhubungan laut-darat, maka dalam menentukan lokasi pelabuhan harus mempertimbangkan interkoneksi dengan prasarana dan sarana angkutan darat. Hal ini khususnya berkaitan dengan apakah perlu membuka jalan baru untuk menghubungkan antara pelabuhan dengan jalan utama serta biaya yang harus disediakan untuk pembukaan jalan baru tersebut. Kriteria ini sangat penting karena merupakan penentu dalam kelancaran transportasi di darat, sehingga bobot diberikan adalah 14\%. Berikut adalah nilai untuk masing-masing indikator aksesibilitas.

Kriteria ketersediaan lahan sangat penting dan sangat menentukan, karena ketersediaan lahan akan sangat berpengaruh terhadap pengembangan pelabuhan di masa yang akan datang. Hal ini terkait dengan kesediaan 
pemerintah untuk peruntukan areal dermaga, dilain pihak adalah kesesuaian antara lokasi dermaga dengan arah kebijakan maupun tata ruang daerah yang telah ditentukan. Berbeda dengan indikator yang digunakan pada studi di Pelabuhan Makian, indikator yang digunakan pada tugas akhir ini adalah kepemilikan dan pemanfaatan lahan. Untuk kepemilikan lahan dibagi menjadi tiga yaitu milik negara, penduduk/pribadi dan kelompok/adat, sedangkan pada studi di Pelabuhan Makian kepemilikan lahan dibedakan menjadi tanah negara dan tanah pribadi. Untuk pemanfaatan lahan dibagi menjadi empat yaitu tanah kosong, pertanian, pemukiman dan kawasan suci, sedangkan pada studi Pelabuhan Makian pemanfaatan lahan yang digunakan adalah lahan kosong dan ada bangunan yang dapat dibebaskan dan tidak dapat dibebaskan.

Untuk status kepemilikan lahan, tanah negara diberi nilai yang tinggi karena berkaitan dengan kemudahan pembebasan dan ganti rugi yang relatif lebih murah. Sedangkan untuk pemanfaatan lahan (landuse), tanah kosong diberi nilai besar karena berkaitan dengan kemudahan dalam persiapan pembangunan. Mengingat bahwa ketersediaan lahan sangat penting dan mutlak dalam pengembangan pelabuhan maka diberi bobot 14 .

Beberapa pertimbangan yang berkaitan dengan kondisi lahan untuk fasilitas areal darat yaitu daya dukung tanah, bebas dari pengaruh pasang surut dan kondisi lahan yang cukup landai. Pertimbangan tersebut perlu diperhatikan agar hal-hal yang merugikan dapat diantisipasi dalam disain. Pertimbangan kemiringan lahan sangat berpengaruh terhadap erosi permukaan tanah maupun mobilisasi moda transportasi yang ada. Dengan demikian kondisi lahan cukup penting dalam pembangunan pelabuhan dan bobot yang diberikan adalah 8 .

Indikator yang digunakan dalam faktor pendukung adalah keberadaan fasilitas air bersih, listrik, komunikasi, dan bahan bakar. Indikator-indikator ini tidak mutlak harus sudah tersedia, namun keberadaannya cukup penting untuk mengurangi pembangunan fasilitas didalam lokasi pelabuhan sekaligus mengurangi anggaran pembangunan. Mengingat hal tersebut maka bobot untuk kriteria ini diberikan 7. Dari uraian mengenai tingkat kepentingan setiap faktor tersebut diatas akan disajikan dalam Tabel 3.

Dari tingkat kepentingan tersebut diatas diperoleh bobot penilaiannya. Untuk mendapatkan bobot yang lebih tepat dan dapat dipertanggungjawabkan maka diperlukan suatu analisis terhadap persentase pembobotan ini dengan metode statistik tertentu. Namun pada tugas akhir ini persentase pembobotan yang digunakan mengacu kepada pembobotan Departemen Perhubungan berdasarkan asas kepentingan. Selanjutnya nilai dari masing-masing faktor di atas dimasukkan ke dalam matrik penilaian pada Tabel 4.

Berdasarkan tabel di atas total nilai yang diperoleh pada lokasi alternatif 2 adalah yang terbesar. Karena rata-rata nilai yang diperoleh alternatif ini merupakan nilai rata-rata terbesar pada setiap faktor yang dtinjau. Faktor-faktor tersebut yaitu jarak kedalaman minimum, sedimentasi, alur pelayaran, aksesibilitas dan ketersediaan lahan. Dilihat dari jarak kedalaman minimumnya alternatif ini memiliki jarak $35-50 \mathrm{~m}$ dari garis pantai sehingga mendapat nilai 9. Dari faktor sedimentasi jarak lokasi ke sungai terdekat adalah $215 \mathrm{~m}$ sehingga berdasarkan kriteria penilaian yang digunakan alternatif ini diberikan nilai 6. Kemudian untuk alur pelayaran alternatif ini mendapat nilai 10 karena memiliki kedalaman $>1,5 \mathrm{D}$ dan lebar $>10$ L. Pada faktor aksesibilitas, alternatif ini mendapat nilai 8 karena lokasi berada dekat dengan jalan arteri, kondisi alinyemen yang relatif datar dan berada di luar kota. Untuk faktor ketersediaan lahan alternatif ini mendapat nilai 7 karena lahan yang tersedia merupakan milik pribadi yang merupakan kawasan nelayan.

Tabel 3

Tabulasi Tingkat Kepentingan Aspek Teknis.

\begin{tabular}{|l|c|c|c|c|}
\hline \multicolumn{1}{|c|}{ Faktor } & $\begin{array}{c}\text { Sangat } \\
\text { penting }\end{array}$ & Penting & $\begin{array}{c}\text { Cukup } \\
\text { penting }\end{array}$ & $\begin{array}{c}\text { Tidak } \\
\text { penting }\end{array}$ \\
\cline { 2 - 5 } & $(11-14) \%$ & $(8-10) \%$ & $(4-7) \%$ & $(0-3) \%$ \\
\hline $\begin{array}{l}\text { Jarak Kedalaman } \\
\text { Minimum }\end{array}$ & - & $\sqrt{ }$ & - & - \\
\hline Arus Dominan & - & $\sqrt{ }$ & - & - \\
\hline Pasang Surut & - & $\sqrt{ }$ & - & - \\
\hline $\begin{array}{l}\text { Gelombang } \\
\text { Dominan }\end{array}$ & $\sqrt{ }$ & - & - & - \\
\hline Sedimentasi & - & $\sqrt{ }$ & - & - \\
\hline Alur Pelayaran & $\sqrt{ }$ & - & - & - \\
\hline Aksesibilitas & $\sqrt{ }$ & - & - & - \\
\hline Ketersediaan Lahan & $\sqrt{ }$ & - & - & - \\
\hline Kondisi Lahan & - & $\sqrt{ }$ & - & - \\
\hline $\begin{array}{l}\text { Fasilitas } \\
\text { Pendukung }\end{array}$ & - & - & $\sqrt{ }$ & - \\
\hline
\end{tabular}

Sumber: Studi Pelabuhan Penyeberangan (Makian, 2007)

Tabel 4.

Matriks Penilaian Aspek Teknis

\begin{tabular}{|c|c|c|c|c|c|c|c|c|c|c|}
\hline \multirow{2}{*}{ No } & \multirow{2}{*}{ Traian } & \multirow{2}{*}{$\begin{array}{l}\text { B } \\
\%\end{array}$} & \multicolumn{2}{|c|}{ Alt. 1} & \multicolumn{2}{|c|}{ Alt. 2} & \multicolumn{2}{|c|}{ Alt. 3} & \multicolumn{2}{|c|}{ Alt. 4} \\
\hline & & & $\mathbf{N}$ & $B * N$ & $\mathbf{N}$ & $B * N$ & $\mathbf{N}$ & $\mathbf{B} * \mathbf{N}$ & $\mathbf{N}$ & $B * N$ \\
\hline 1 & $\begin{array}{l}\text { Jarak } \\
\text { kedalaman } \\
\text { minimum } \\
\end{array}$ & 9 & 8 & 72 & 9 & 81 & 7 & 63 & 8 & 72 \\
\hline 2 & $\begin{array}{l}\text { Arus } \\
\text { dominan }\end{array}$ & 9 & 5 & 45 & 5 & 45 & 5 & 45 & 5 & 45 \\
\hline 3 & Pasang surut & 8 & 6 & 48 & 6 & 48 & 6 & 48 & 6 & 48 \\
\hline 4 & $\begin{array}{l}\text { Gelombang } \\
\text { dominan }\end{array}$ & 11 & 6 & 66 & 4 & 44 & 4 & 44 & 4 & 44 \\
\hline 5 & Sedimentasi & 9 & 5 & 45 & 6 & 54 & 6 & 54 & 5 & 45 \\
\hline 6 & $\begin{array}{l}\text { Alur } \\
\text { pelayaran }\end{array}$ & 11 & 6 & 66 & 10 & 110 & 10 & 110 & 10 & 110 \\
\hline 7 & Aksesibilitas & 14 & 8 & 112 & 8 & 112 & 8 & 112 & 6 & 84 \\
\hline 8 & $\begin{array}{l}\text { Ketersediaan } \\
\text { lahan }\end{array}$ & 14 & 6 & 84 & 7 & 98 & 3 & 42 & 7 & 98 \\
\hline 9 & $\begin{array}{l}\text { Kondisi } \\
\text { Lahan }\end{array}$ & 8 & 8 & 64 & 10 & 80 & 10 & 80 & 10 & 80 \\
\hline 10 & \begin{tabular}{|l} 
Fasilitas \\
pendukung
\end{tabular} & 7 & 9 & 63 & 9 & 63 & 9 & 63 & 9 & 63 \\
\hline & Total : & 100 & & & 665 & & 735 & & 661 & \\
\hline
\end{tabular}

Ket: $\mathrm{B}=$ Bobot; $\mathrm{N}=$ Nilai; Alt. = Alternatif 
Dibandingkan dengan alternatif 2, alternatif 4 berada di urutan ke dua setelah alternatif 2. Lokasi 4 mendapat nilai yang kecil untuk faktor sedimentasi dan aksesibilitas. Seperti yang sudah dijelaskan pada subbab sebelumnya lokasi ini berada dekat dengan Tukad Bangka dan dengan alinyemen jalan yang curam karena harus melintasi perbukitan yang berada di belakangnya.

Alternatif 1 berada di urutan ke tiga setelah alternatif 4 . Seperti pada alternatif 4, alternatif ini berada dekat dengan sungai sehingga nilai dari sedimentasi untuk lokasi ini diberikan kecil. Ketersediaan dan kondisi lahan lokasi ini juga mendapat nilai yang kecil karena untuk alur pelayaran lokasi ini berada pada sebuah teluk, sehingga lebar alur dibatasi oleh lebar teluk tersebut. Dari kondisi dan ketersediaan lahan, lahan yang ada merupakan pemukiman penduduk dan kemiringan lahannya sebesar $14,38 \%$.

Alternatif yang memiliki nilai terkecil adalah alternatif 3. Dari faktor ketersediaan lahan yang merupakan faktor terpenting selain aksesbilitas lokasi ini mendapat nilai terkecil karena lahan di lokasi ini merupakan kawasan tempat suci yaitu tempat melasti.

Dari total nilai keempat alternatif yang diperoleh, alternatif 2 mendapat nilai terbesar yaitu 735 sehingga merupakan alternatif yang memiliki kelayakan terbaik dari aspek teknis.

\subsection{Analisis Sosial}

Aspek sosial dianggap terpenuhi jika masyarakat di lokasi bersangkutan mendukung adanya pembangunan pelabuhan di daerah tersebut. Untuk mendapatkan data sosial yang diperlukan maka dilakukan survei aspirasi masyarakat melalui penyebaran kuisioner secara sampling berdasarkan tingkat keterwakilan masyarakat dan melalui rembug warga (focus group discussion) oleh Tim Lembaga Penelitian (Lemlit) UNUD.

Pada tanggal 22 Agustus 2006 Tim Lemlit UNUD mengundang masyarakat setempat pada masing-masing lokasi alternatif ke Balai Desa Purwakerti untuk mengadakan rembug warga (focus group discussion). Kegiatan ini hanya dihadiri oleh 39 anggota masyarakat dan dari penyebaran kuesioner kepada 39 orang tersebut, hanya 35 buah yang berhasil dikumpulkan kembali. Hal ini kemungkinan karena masyarakat kurang mengerti bahwa hasil dari rembug warga tersebut penting dalam Perencanaan Pelabuhan Amed.

Hasil yang didapat tersebut belum memenuhi persyaratan dalam pengambilan sampel sehingga harus dilakukan penelitin ulang. Dikarenakan oleh keterbatasan waktu, biaya dan tenaga penelitian aspek sosial lebih lanjut tidak dapat dilakukan, sehingga tugas akhir tidak mendiskusikan aspek sosial.

\subsection{Analisis Legalitas}

Analisis pada aspek legalitas dilakukan dengan meninjau kesesuaian lokasi dengan peraturan-peraturan terkait. Berikut adalah tinjauan pada peraturan-peraturan yang berhubungan dengan penentuan lokasi sebuah pelabuhan penyeberangan.
Dalam Rencana Tata Ruang Propinsi Bali bagian keempat tentang pengembangan sistem prasarana wilayah yaitu pada pasal 33 ayat 2 (c) disebutkan mengenai Pengembangan Pelabuhan Penyeberangan Amed. Selanjutnya pada bagian kelima mengenai wilayah prioritas pasal 34 ayat 1 (d) disebutkan bahwa wilayah prioritas Bali Timur meliputi Kecamatan Kintamani, Kubu, Abang, dan Karangasem diarahkan pada pengentasan desa tertinggal, penanggulangan lahan kritis, pengembangan pariwisata, pertanian, dan pertambangan galian $\mathrm{C}$.

Dengan adanya dasar tersebut dapat disimpulkan bahwa Perencanaan Pelabuhan Amed tidak bertentangan dengan Rencana Tata Ruang Propinsi Bali, bahkan dengan adanya Pelabuhan Amed diharapkan dapat menunjang pengembangan Desa Purwakerti.

Pada pasal 28 sub c Rencana Tata Ruang Wilayah Kabupaten Karangasem disebutkan bahwa areal kawasan Pariwisata Tulamben meliputi pantai wilayah Desa Datah, pantai wilayah Desa Labasari, pantai wilayah Desa Culik, pantai wilayah Desa Purwakerti, pantai wilayah Desa Bunutan.

Dalam arahan kebijakan di bidang transportasi pada tingkat kabupaten Karangasem (Tataran Transportasi Lokal/Tatralok) disebutkan adanya rencana pengembangan Amed sebagai Pelabuhan Penyeberangan. Dalam Tatralok Kabupaten Karangasem, pengembangan Pelabuhan Penyeberangan Amed dilakukan dalam tiga jangka waktu pelaksanaan yaitu jangka pendek, menengah dan panjang.

Tabel 5.

Rencana Program Pembangunan Pelabuhan Amed Tahun 20062030

\begin{tabular}{|c|c|c|c|c|}
\hline \multirow[b]{2}{*}{ Program } & \multirow[b]{2}{*}{ Deskripsi } & \multicolumn{3}{|c|}{ Jangka Waktu } \\
\hline & & $\begin{array}{l}\text { Pendek } \\
(2006- \\
2010)\end{array}$ & $\begin{array}{l}\text { Mene- } \\
\text { ngah } \\
(2010- \\
2020)\end{array}$ & $\begin{array}{c}\text { Panjang } \\
(2020- \\
2030)\end{array}$ \\
\hline \multirow{5}{*}{$\begin{array}{l}\text { Pelabuh- } \\
\text { an Amed }\end{array}$} & $\begin{array}{l}\text { - Direncanakan } \\
\text { sebagai pelabuhan } \\
\text { penyeberangan }\end{array}$ & & $\sqrt{ }$ & $\sqrt{ }$ \\
\hline & $\begin{array}{l}\text { - Perencanaan simpul } \\
\text { terminal } \\
\text { intermodality }\end{array}$ & & & $\sqrt{ }$ \\
\hline & - Studi Kelayakan & $\sqrt{ }$ & & \\
\hline & - Penyusunan DED & & $\sqrt{ }$ & \\
\hline & $\begin{array}{l}\text { - Pelaksanaan } \\
\text { Konstruksi }\end{array}$ & & & $\sqrt{ }$ \\
\hline
\end{tabular}

Sumber: Studi Pelabuhan Penyeberangan (Makian, 2007)

Seperti pada RTRW Propinsi Bali, pada prinsipnya pengembangan pelabuhan Amed sebagai pelabuhan penyeberangan tidak bertentangan dengan RTRW Kabupaten Karangasem.

Dalam Rencana Detail Tata Ruang Kawasan Pariwisata (RDTRKP) Tulamben disebutkan rencana sistem pusat pelayanan Kawasan Pariwisata Tulamben. Dari rencana pusat pelayanan tersebut desa Purwakerti difungsikan sebagai berikut:

1. Unit pusat pelayanan kawasan

2. Pusat kegiatan pemerintahan desa 
3. Pusat pelayanan permukiman skala kawasan

4. Kawasan efektif pariwisata (KEP)

5. Pusat Pengembangan Perikanan

6. Pusat Pengembangan transportasi regional.

Rencana pengembangan kegiatan pelabuhan penyeberangan sedapat mungkin tidak mematikan usahausaha masyarakat yang telah berkembang disekitarnya serta mendukung pengembangan kegiatan wisata yang ada. Hal-hal yang dapat dilakukan untuk pengembangan kegiatan pelabuhan penyeberangan adalah sebagai berikut:

1) Pengembangan Pelabuhan Amed sebagai salah satu penunjang kegiatan pariwisata.

2) Pengembangan lokasi pelabuhan diusahakan agar dapat berdampingan dengan pusat pengembangan fasilitas perikanan yang telah berkembang di sekitar Amed yaitu adanya Pangkalan Pendaratan Ikan, Pusat Pelelangan Ikan, dan fasilitas lainnya.

Atas dasar tersebut, Pengembangan Pelabuhan Amed dapat dilakukan selaras dan dapat menunjang kegiatan masyarakat yang telah berkembang sebelumnya. Dengan demikian dapat disimpulkan bahwa Perencanaan Pelabuhan Amed tidak berbenturan dengan Rencana Detail Tata Ruang Kawasan Pariwisata Tulamben.

Dalam Keputusan Menteri Perhubungan No.53 tahun 2002 tentang Tatanan Kepelabuhanan Nasional (TKN) diatur tentang peran, fungsi, kegiatan dan jenis pelabuhan. Menurut kegiatannya Pelabuhan Amed merupakan pelabuhan penyeberangan. Melihat hirarki peran dan fungsi pelabuhan penyeberangannya dengan memperhatikan fungsi jalan yang menghubungkannya yaitu jalan nasional, Pelabuhan Amed termasuk dalam pelabuhan penyeberangan lintas propinsi.

Pada Keputusan Menteri Perhubungan No.52 tahun 2002 tentang Penyelenggaraan Pelabuhan Penyeberangan disebutkan bahwa penetapan lokasi wajib memperhatikan Tatanan Kepelabuhanan Nasional, Kesesuaian dengan Rencana Tata Ruang Wilayah Kabupaten/Kota dan Rencana Tata Ruang Wilayah Propinsi, kelayakan teknis, kelayakan ekonomis, kelayakan lingkungan dan pertahanan dan keamanan negara. Pada batasan penelitian dalam tugas akhir ini tidak dibahas mengenai kelayakan ekonomi, lingkungan dan pertahanan keamanan negara.

Berdasarkan tinjauan dari Rencana Tata Ruang Propinsi dan Kabupaten, Rencana Detail Tata Ruang Kawasan Pariwisata Tulamben dan Tataran Transportasi Lokal diatas diketahui bahwa rencana pengembangan Pelabuhan Penyeberangan Amed tidak mengalami benturan dengan peraturan-peraturan yang ada dan layak dari aspek teknis, sehingga pada dasarnya semua alternatif memenuhi pada aspek legalitas kecuali alternatif 1 yang berada di Teluk Jemuluk yang merupakan lokasi obyek wisata, sehingga lokasi ini tidak sesuai dengan Rencana Detail Tata Ruang Kawasan Pariwisata Tulamben.

\subsection{Lokasi Terpilih}

Berdasarkan analisis di atas lokasi terpilih dari aspek teknis adalah Alternatif 2 yang terletak di Dusun Amed, Desa Purwakerti, Kecamatan Abang. Dari tinjauan legalitas alternatif yang layak adalah Alternatif 2, 3 dan 4, sedangkan dari tinjauan aspek sosial lokasi terpilih tidak didapat karena tinjauan dari aspek ini tidak dilakukan karena data sosial yang didapat tidak memenuhi syarat. Sehingga dengan hanya meninjauan aspek teknis dan legalitas lokasi yang terpilih sebangai Pelabuhan Amed adalah Alternatif 2 dengan koordinat $8^{\circ} 19^{\prime} 56,78^{\prime \prime}$ LS dan $115^{\circ} 38^{\prime} 29,44^{\prime \prime}$ BT.

\section{Simpulan dan Saran}

\subsection{Simpulan}

Berdasarkan hasil anlisis yang dilakukan dengan menggunakan empat alternatif lokasi yang memungkinkan untuk dikembangkan sebagai Pelabuhan Penyeberangan Amed, yaitu :

- Alternatif 1 teletak di Dusun amed, Desa Purwakerti (Teluk Jemuluk) dengan koordinat $8^{\circ} 20^{\prime} 12,85^{\prime \prime}$ LS dan $115^{\circ} 39^{\prime} 37,01$ ” BT.

- Alternatif 2 terletak di Dusun amed, Desa Purwakerti (sebelah utara Pusat Pelelangan Ikan) dengan koordinat $8^{\circ} 19^{\prime} 56,78^{\prime \prime}$ LS dan $115^{\circ} 38^{\prime} 29,44^{\prime \prime}$ BT.

- Alternatif 3 terletak di Dusun Babakan, Desa Purwakerti (sebelah utara tempat melasti) dengan koordinat $8^{\circ} 19^{\prime} 48,18^{\prime \prime}$ LS dan $115^{\circ} 38^{\prime} 25,06^{\prime \prime}$ BT.

- Alternatif 4 terletak di Dusun Babakan, Desa Purwakerti (dekat Tukad Bangka) dengan koordinat $8^{\circ} 19^{\prime} 30,59^{\prime \prime}$ LS dan $115^{\circ} 38^{\prime} 03,45^{\prime \prime}$ BT.

Dalam analisis kebutuhan lahan daratan dan perairan digunakan kapal rencana dengan bobot 2000 GRT. Karakteristik kapal rencana sebagai berikut:

$\begin{array}{lll}\text { - } \mathrm{L}_{\mathrm{OA}} \text { (Length Overall) } & : & 90 \mathrm{~m} \\ \text { - Lebar } & : & 16,2 \mathrm{~m} \\ \text { - Draft } & : & 4,3 \mathrm{~m} \\ \text { - Kapasitas penumpang } & : & 516 \text { orang } \\ \text { - Kapasitas kendaraan } & : & 35 \text { unit }\end{array}$

Total kebutuhan lahan minimum yang diperlukan untuk fasilitas daratan adalah $0,7 \mathrm{Ha}$ dan kebutuhan untuk fasilitas perairan adalah 15,8 Ha. Tipe dermaga yang digunakan adalah tipe wharf, karena jarak kedalaman yang diperlukan yaitu $-5,5 \mathrm{~m}$ sudah didapat pada jarak yang dekat yaitu 70-105 $\mathrm{m}$ dari garis pantai.

Berdasarkan tinjauan dari aspek teknis dengan analisis pembobotan didapat total nilai untuk masing-masing alternatif adalah Alternatif 1 dengan nilai 665, Alternatif 2 dengan nilai 735, Alternatif 3 dengan nilai 661 dan Alternatif 4 dengan nilai 689, sehingga dari tinjauan aspek teknis lokasi terpilih adalah alternatif 2, sedangkan Analisis dari aspek sosial tidak dapat dilakukan karena data sosial yang didapat sampai berakhirnya waktu penelitian ini tidak memenuhi syarat dalam pengambilan sampel. Pada aspek legalitas dengan meninjau peraturan yang terkait dengan pembangunan pelabuhan penyeberangan yaitu RTRW Propinsi Bali, RTRW Kabupaten Karangasem, RDTRKP Tulamben, Keputusan Menteri No.52 tahun 2002 dan Keputusan Menteri No.53 tahun 2002, semua alternatif dapat dikatakan layak kecuali alternatif 1 karena berbenturan dengan RDTRKP Tulamben. Dengan hanya meninjau aspek teknis dan 
legalitas lokasi terpilih adalah alternatif 2 yang terletak di Dusun Amed, Desa Purwakerti.

\subsection{Saran}

Beberapa saran yang dapat dikemukakan dan bisa dipakai sebagai bahan pertimbangan dalam pembangunan pelabuhan ini adalah :

1. Perlu dilakukan studi dan survei khusus untuk mengetahui kemungkinan besarnya sedimentasi, mengingat di pantai Amed banyak bermuara sungai yang kemungkinan akan membawa sedimen ke perairan pelabuhan.

2. Perlu dilakukan sosialisasi lebih lanjut kepada masyarakat mengenai Perencanaan Pelabuhan Amed, sehingga dapat dilakukan kajian ulang untuk aspek sosial sesuai metode yang ada.

3. Perlu dilakukan kajian mengenai perkiraan arus muatan penupang, barang dan kendaraan yang akan menggunakan pelabuhan Amed.

4. Perlu dilakukan kajian lebih mendalam mengenai penilaian pembobotan untuk masing-masing kriteria penilaian.

\section{Daftar Pustaka}

Adizha Marathon, PT. (2004). Laporan Draft Final Pekerjaan Survey, Desain dan Investigasi Dermaga Penyeberangan Padang Bai II (Bali) - Lembar II (NTB). Direktorat Jenderal Perhubungan Darat, Departemen Perhubungan, Jakarta.

Artamana, I. B. M. (2007). Pemilihan Lokasi Pelabuhan Ditinjau Dari Aspek Teknis Dan Legalitas. Tugas Akhir. Program Studi Teknik Sipil, Fakultas Teknik, Universitas Udayana, Denpasar.

BPS Karangasem. (2006). Abang Dalam Angka 2006. Badan Pusat Statistik Kabupaten Karangasem.

BPS Bali. (2008). Bali Dalam Angka 2008. Badan Pusat Statistik Provinsi Bali.

BPS Karangasem. (2008). Karangasem Dalam Angka 2008. Badan Pusat Statistik Kabupaten Karangasem.

Budiartha, N, \& Arnatha, M. (1999). Pelabuhan Edisi Pertama. Denpasar: Guna Widya.
Dishub Provinsi Bali. (2008). Perhubungan Dalam Angka 2008. Dinas Perhubungan Provinsi Bali, Departemen Perhubungan, Denpasar.

Direktorat Pelabuhan dan Pengerukan. (2003). Pedoman Penyusunan Rencana Induk Pelabuhan. Direktorat Pelabuhan dan Pengerukan, Jakarta.

Direktorat Pelabuhan dan Pengerukan. (2003). Pedoman Teknis Pemilihan Dan Penetapan Lokasi Pelabuhan Di Indonesia. Direktorat Pelabuhan dan Pengerukan, Jakarta.

Keputusan Menteri Perhubungan Nomor 52 tentang Penyelenggaraan Pelabuhan Penyeberangan. 2002. Departemen Perhubungan, Jakarta.

Keputusan Menteri Perhubungan Nomor 53 tentang Tatanan Kepelabuhanan Nasional. 2002. Departemen Perhubungan, Jakarta.

Keputusan Menteri Perhubungan Nomor 54 tentang Penyelenggaraan Pelabuhan Laut. 2002. Departemen Perhubungan, Jakarta.

Kramadibrata, S. (2002). Perencanaan Pelabuhan. Institut Teknologi Bandung, Bandung.

Lembaga Penelitian Universitas Udayana. 2006. Laporan Akhir Kegiatan Penyusunan Tataran Transportasi Lokal di Karangasem.. Dinas Perhubungan, Pemerintah Kabupaten Karangasem.

Lembaga Penelitian Universitas Udayana. (2006). Laporan Akhir Studi Kelayakan Pembangunan Pelabuhan Amed. Dinas Perhubungan, Pemerintah Provinsi Bali, Denpasar.

Peraturan Daerah Kabupaten Karangasem Nomor 11 Tahun 2000 tentang Rencana Tata Ruang Wilayah Kabupaten Karangasem. 2000. Setda Kabupaten Karangasem.

Peraturan Daerah Provinsi Bali Nomor 3 Tahun 2005 tentang Rencana Tata Ruang Wilayah Provinsi Bali. 2005. Pemerintah Provinsi Bali.

Spektra Adhya Prasarana. (2007). Studi Detail Engineering Design Pelabuhan Amed. Dinas Perhubungan, Pemerintah Provinsi Bali, Denpasar.

Sugiarto, D. S., Sunaryanto, L. T., \& Oetomo, D. S. (2003). Teknik Sampling. Gramedia Pustaka Utama, Jakarta.

Triatmodjo, B. (2003). Pelabuhan. Beta Offset, Yogyakarta.

Tridaya Cipta Pratama, PT. (2007). Detailed Engineering Design Pelabuhan Penyeberangan Makian. Direktorat Jenderal Perhubungan Darat, Departemen Perhubungan, Jakarta.

(C) 2016 by the authors; licensee Udayana University, Indonesia. This article is an open access article distributed under the terms and conditions of the Creative Commons Attribution license (http://creativecommons.org/licenses/by/3.0/). 